\title{
Does the first LH surge of the breeding season initiate the first full-length cycle in the ewe?
}

\author{
H. I'Anson and S. J. Legan \\ Department of Physiology and Biophysics, University of Kentucky, Lexington, KY 40536-0084, \\ U.S.A.
}

\begin{abstract}
Summary. To determine whether the first LH surge of the breeding season initiates a transient rise in progesterone in most ewes, serum progesterone (daily) and $\mathrm{LH}$ (every $4 \mathrm{~h}$ ) concentrations were measured in samples collected from 7 ewes between 19 July and first oestrus or 8 September, whichever came first. In 6 of the 7 ewes, the first $\mathbf{L H}$ surge of the breeding season was followed within 5 days by a transient, 2-day rise in progesterone. Within less than $5(\mathrm{~N}=4)$, or $9(\mathrm{~N}=1)$ or $10(\mathrm{~N}=1)$ days later, a second LH surge occurred, which was similar in maximum amplitude and duration to the first surge, and which initiated the first full-length luteal phase of the breeding season. In the remaining ewe, the first LH surge of the breeding season induced an abbreviated ( 9 days) and insufficient (maximum progesterone, $0.94 \mathrm{ng} / \mathrm{ml}$ ) luteal phase. These results demonstrate that most ewes have more than one LH surge before the first full-length luteal phase, the first surge inducing a transient rise in progesterone. Therefore, although the seasonal decrease in response to oestradiol negative feedback is sufficient for initiation of the first LH surge of the breeding season, additional endocrine mechanisms may be necessary to induce the first full-length luteal phase.
\end{abstract}

Keywords: seasonal transition; LH surge; serum LH; short luteal phases; progesterone

\section{Introduction}

According to the current hypothesis for the endocrine control of the transition to breeding season, a short-day-induced decrease in response to oestradiol negative feedback results in an abrupt increase in LH pulse frequency (Karsch, 1980; Goodman \& Karsch, 1981). This in turn stimulates a rise in oestradiol secretion, which ultimately attains the threshold required to elicit an LH surge, resulting in ovulation, and thus the beginning of the breeding season (Karsch et al., 1980b). However, in the majority of ewes the first rise in progesterone which occurs at the transition from anoestrus to the breeding season is not a full-length luteal phase. Rather, one or more transient rises in progesterone occurs between 1 and 4 weeks before the first full-length cycle (Yuthasastrakosol et al., 1975; Walton et al., 1977; I'Anson \& Legan, 1988). If the first brief rises in progesterone observed during the transition to breeding season are caused by the first LH surge, then the above sequence of events may be sufficient for induction of LH surges, but not full-length cycles, indicating that additional endocrine mechanisms may be necessary to induce the first full-length luteal phase of the breeding season.

That there is an LH surge before each transient rise in progesterone is supported by the observations that serum $\mathrm{LH}$ concentrations were $19 \cdot 1 \pm 8 \cdot 2 \mathrm{ng} / \mathrm{ml}(\mathrm{N}=8) 3$ days before a transient progesterone rise (Walton et al., 1977) and that serum LH concentrations were $>20 \mathrm{ng} / \mathrm{ml}(\mathrm{N}=3$ ) about I week before the first full-length luteal phase (Yuthasastrakosol et al., 1975). Although the daily sampling regimen used in these 2 studies was too infrequent to detect an 8-12 h-long LH surge reliably, part of an LH surge was observed 5 days before the first transient increase in progesterone 
at the beginning of the breeding season in one of 8 ewes sampled every $15 \mathrm{~min}$ for $8 \mathrm{~h}$ (I'Anson \& Legan, 1988). Finally, additional supportive evidence is provided by the observations that when oestrous cycles are induced in anoestrus, the first LH surge initiates a short luteal phase in most ewes (Oldham \& Martin, 1978; McNatty et al., 1982; McLeod et al., 1982a, b; Pearce et al., 1985; Legan et al., 1985a, b). Therefore, the following study was designed to determine whether most first LH surges at the transition to the breeding season induce transient rises in progesterone rather than full-length luteal phases.

\section{Materials and Methods}

Animals. Thirteen Suffolk or Suffolk-crossbred ewes were maintained in an outdoor pen at the Sheep Research Facility in Ann Arbor, Michigan ( $42^{\circ} \mathrm{N}$ latitude), in the presence of rams. All animals were fed hay and had free access to mineral licks and water.

Experimental procedure and blood samples. To determine when LH surges occurred during the transition to breeding season, blood samples ( $7 \mathrm{ml}$ ) were obtained by jugular venepuncture every $4 \mathrm{~h}$ from 19 July to first oestrus or 8 September, whichever came first. Oestrous behavior was monitored daily using a raddled vasectomized ram, which was introduced on the 2 nd day of this study ( $20 \mathrm{July}$ ) (Karsch et al., 1980a). To establish occurrence of the first luteal phase of the breeding season and any antecedent rises in progesterone, serum progesterone concentrations were measured in daily blood samples obtained throughout the previously-defined experimental period.

Blood samples were stored overnight at $4^{\circ} \mathrm{C}$. Sera were separated and stored at $-20^{\circ} \mathrm{C}$ until assayed.

Radioimmunoassays. LH concentrations were determined in duplicate in 2.5 to $200 \mu$ l volumes of serum by a radioimmunoassay (Niswender et al., 1969), which was modified as described previously (Legan et al., 1985a). The limit of detection ( $95 \%$ confidence limit of maximum binding) averaged $0.18 \mathrm{ng} / \mathrm{ml}$ for $200 \mu \mathrm{l}$ serum. The intra- and inter-assay coefficients of variation (CV) for $200 \mu \mathrm{l}$ samples of a serum pool containing $1.02 \mathrm{ng} / \mathrm{ml} \mathrm{LH}(n=18)$, which inhibited binding of labelled ligand to $50.6 \%$, averaged $9.3 \%$ and $15.8 \%$, respectively. $\mathrm{LH}$ concentrations were expressed in terms of the NIAMDD ovine LH reference preparation, Batch 21, which has a potency of 1.86 times that of $\mathrm{NIH}-\mathrm{LH}-\mathrm{S} 12$, as we determined by radioimmunoassay.

Progesterone concentrations were measured in duplicate petroleum ether extracts of $150 \mu \mathrm{l}$ serum by a modification (Legan et al., 1985a) of a radioimmunoassay described previously (Gibori et al., 1977). Assay sensitivity $(95 \%$ confidence limits of maximum binding) averaged $0.14 \mathrm{ng} / \mathrm{ml}$ for $150 \mu \mathrm{l}$ serum, and ether and water blanks were routinely below this value. Intra- and inter-assay CVs averaged $14.1 \%$ and $24.7 \%(n=22)$, respectively, for $100 \mu 1$ samples of a serum pool from intact ewes which inhibited binding of labelled ligand to about $50.7 \%$ and contained $3.54 \mathrm{ng} / \mathrm{ml}$ progesterone.

Statistical analysis. Statistical analyses were performed using Student's $t$ tests, paired $t$ tests, or within-subjects, repeated-measures analyses of variance (BMDP Statistical Software, 1983; SAS Institute, Inc.) with time as the repeated-measures factor. The relationship between mean serum LH and time was also analysed using linear regression. Undetectable hormone concentrations were assigned a value equivalent to the limit of detection of the assay. Results are presented as mean \pm s.e.m.

\section{Results}

All ewes were exposed to new rams, which were moved into an adjacent pen about 1 week before the beginning of this study. In 9 of the 13 ewes either a transient rise in progesterone $(\mathrm{N}=3)$ or a full-length luteal phase $(\mathrm{N}=6)$ was detected during the next 1-2 weeks. To avoid any possible effect of these ram-induced endocrine events on the onset of cycles, the results from 6 ewes, whose first full-length cycle began less than 3 weeks after the end of these ram-induced luteal phases, were excluded from the study.

The mean date of onset of the breeding season (onset of first full-length cycle) for those ewes included in the study was 28 August \pm 2 days $(N=7)$. This date is similar to that reported previously for Suffolk ewes ( 3 September \pm 5 days, Robinson \& Karsch, 1984; 3 September \pm 3 days, I'Anson \& Legan, 1988).

Serum progesterone concentrations remained low in all 7 ewes $(0.17 \pm 0.02 \mathrm{ng} / \mathrm{ml})$ until after the first LH surge of the breeding season (Fig. 1). In one ewe, the first cycle lasted 12 days (progesterone $>0.4 \mathrm{ng} / \mathrm{ml}$ for 6 days) and was insufficient as defined by a maximum serum progesterone value less than $1.00 \mathrm{ng} / \mathrm{ml}$ (Fig. 2a). In the remaining 6 ewes, during the 2-week period before the 


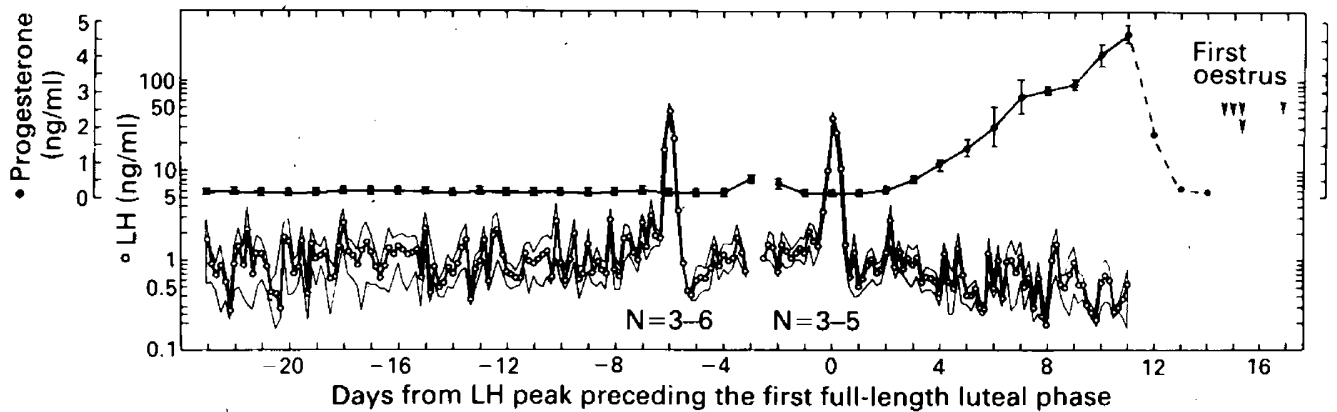

Fig. 1. Mean ( \pm s.e.m.) serum $\mathrm{LH}(O)$ and progesterone $(O)$ concentrations during the transition into the breeding season. In 6 of 7 ewes, the first LH surge of the breeding season was followed by a brief increment in progesterone. Data from Days -23 to -3 were normalized to the first LH surge; those thereafter to the second surge.

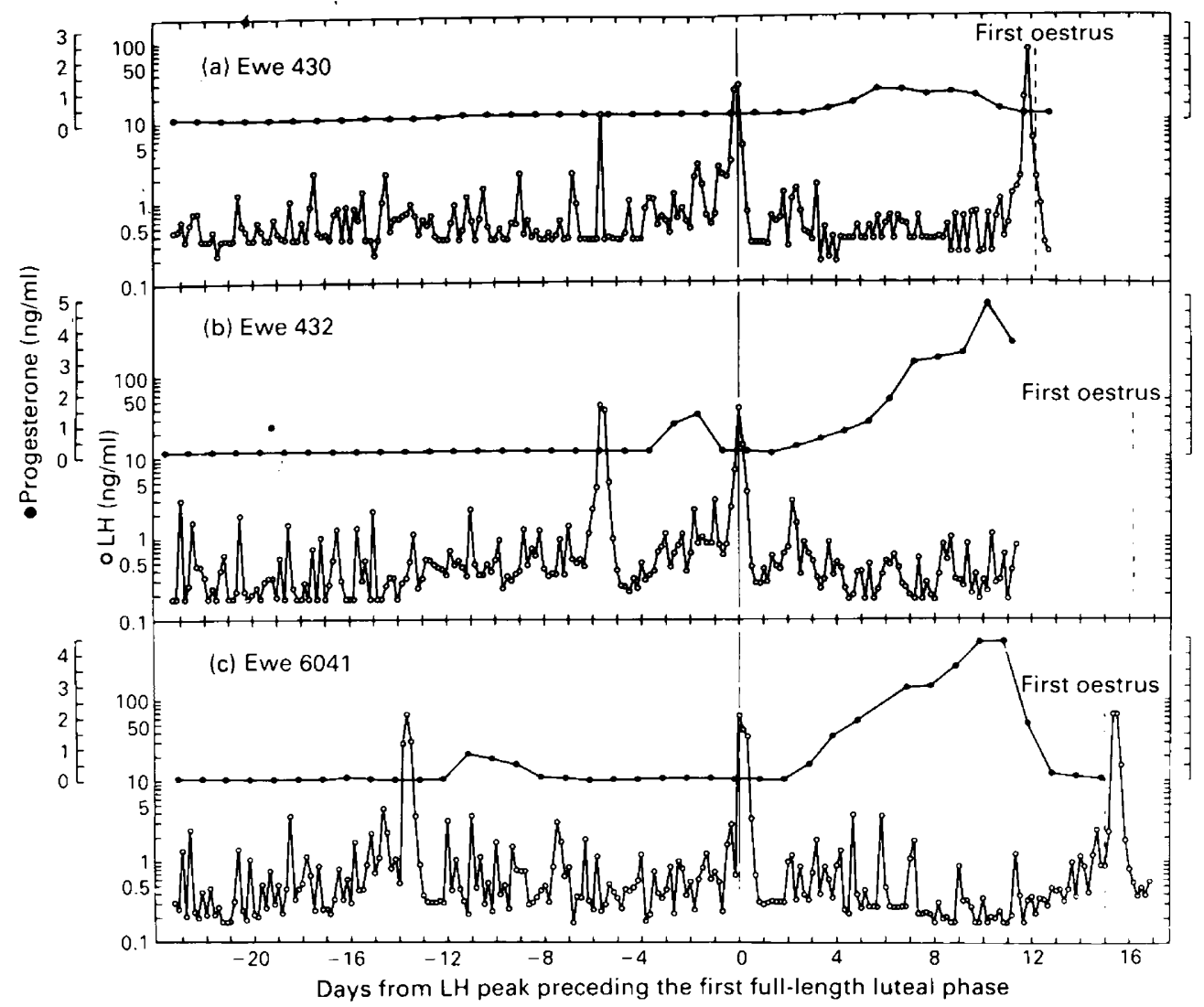

Fig. 2. Serum LH concentrations in samples obtained every $4 \mathrm{~h}(\mathrm{O})$, and daily circulating progesterone concentrations $(\Theta)$ during the transition to the breeding season in 3 representative ewes. See text for further details. 
first full-length luteal phase, there was a transient rise in progesterone lasting for $2.00 \pm 0.36$ days, the maximum concentration averaging $0.81 \pm 0.13 \mathrm{ng} / \mathrm{ml}$. In 4 of these 6 ewes, the transient rises in progesterone occurred $2.25 \pm 0.63$ days before the LH surge which led to the first full-length luteal phase (one representative ewe, Fig. 2b), while in the other two ewes, they were observed 9 and 10 days before this surge (one representative ewe, Fig. 2c).

An LH surge was observed within $3.17 \pm 0.17$ days $(\mathrm{N}=6)$ before each transient rise in progesterone and within $3.43 \pm 0.37$ days $(\mathrm{N}=7$ ) before each first full-length luteal phase (Fig. 1). There was no difference between the first and second LH surges in either the maximum amplitude $(47.64 \pm 6.20$ and $39.08 \pm 5.80 \mathrm{ng} / \mathrm{ml}, 6$ ewes $)$ or duration $(10.67 \pm 0.84$ and $12.67 \pm 1.60 \mathrm{~h}, \mathrm{LH}$ $>5.0 \mathrm{ng} / \mathrm{ml}, 6$ ewes).

Mean serum $\mathrm{LH}$ remained at basal concentrations $(1.08 \pm 0.22 \mathrm{ng} / \mathrm{ml}, 7$ ewes) during the transition to the breeding season until $\sim 44 \mathrm{~h}$ before the first LH surge, when concentrations began to rise from $0.94 \pm 0.28$ to $2.32 \pm 0.36 \mathrm{ng} / \mathrm{ml}$ ( 7 ewes) just before the onset of the surge. The preovulatory rises in mean tonic LH concentrations which occurred during the $44 \mathrm{~h}$ before the first and second surges were not different $(1.03 \pm 0.32$ to $2.21 \pm 0.41 \mathrm{ng} / \mathrm{ml}$, slope $=0.14$, and $1.08 \pm 0.47$ to $2 \cdot 18 \pm 0.54 \mathrm{ng} / \mathrm{ml}$, slope $=0.09,6$ ewes, Fig. 1$)$

Mean tonic LH concentrations during the transient progesterone rises which occurred within 4 days of onset of the second LH surge were not different from those during an equivalent period (of both duration and time) before the first LH surge, when progesterone values were basal $(1.37 \pm 0.22$ and $1.53 \pm 0.51 \mathrm{ng} / \mathrm{ml}, 4$ ewes $)$.

Oestrous behaviour was detected in all ewes after the first full-length luteal phase, and in the ewe in which the luteal phase was insufficient (Ewe 430, Fig. 2a). In contrast, oestrous behaviour was not detected after the transient rises in progesterone.

\section{Discussion}

The foregoing results support previous observations that transient rises in progesterone occur just before the first full-length luteal phase of the breeding season (Yuthasastrakosol et al., 1975; Walton et al., 1977; I'Anson \& Legan, 1988). Such transient progesterone rises are a common phenomenon at transitions from acyclicity to cyclicity, for example, after induction of LH surges in anoestrous ewes (Pearce et al., 1985; Legan et al., 1985a; Hunter et al., 1986), at puberty in lambs (Foster \& Ryan, 1979; Berardinelli et al., 1980; Keisler et al., 1983; Foster et al., 1986), heifers (Gonzalez-Padilla et al., 1975), rhesus monkeys (Foster, 1977; Nass et al., 1979) and humans (Doring, 1969), at resumption of cycles in post-partum cows (Pope et al., 1969) and women (Gray et al., 1987), and at onset of the breeding season in dairy goats (BonDurant et al., 1981). The foregoing results also extend previous observations by demonstrating that, in most ewes, the first LH surge of the breeding season leads to such a transient rise in progesterone rather than a fulllength luteal phase. Thus, they suggest that the seasonal decrease in oestradiol negative feedback, which initiates the events leading to the first LH surge, may not be sufficient in most cases for initiation of full-length oestrous cycles, and that additional endocrine mechanisms are required.

Transient rises in progesterone play a key role in the initiation of full length cycles. In anoestrous ewes, an antecedent, transient progesterone rise similar to those occurring at the beginning of the breeding season ensures incidence of a full-length luteal phase following induction of an LH surge (Oldham \& Martin, 1978; Legan et al., 1985b). Similarly, at the transition to the breeding season as reported herein, all LH surges which occurred immediately after a transient increase in progesterone initiated a full-length luteal phase. It has been suggested that progesterone may ensure full-length luteal phases by synchronizing maturation of a follicle with the LH surge (Legan et al., 1985b). This hypothesis is based on the finding that follicular development occurs throughout anoestrus in ewes (McNatty et al., 1984), and on the proposal that short luteal phases result from ovulation of immature follicles (McLeod et al., 1982b). 
How might an antecedent increment in progesterone synchronize follicular maturation with an LH surge and thereby ensure initiation of a full-length luteal phase? One possible mode of action may be by altering tonic $\mathrm{LH}$ concentrations preceding the LH surge. However, our finding that both the mean basal serum LH concentrations and the preovulatory increments in serum LH before the first and second LH surges were similar indicates that the transient rises in progesterone do not ensure initiation of full-length cycles by altering tonic $\mathrm{LH}$ levels.

Another possible mode of action of progesterone in this regard might be to alter the amplitude, duration or time of onset of the LH surge. The similarity in the amplitude and duration of the first and second LH surges observed in this study indicates that brief increments in progesterone do not affect the amplitude or duration of the subsequent LH surge, as has also been shown in GnRHtreated anoestrous ewes (Legan et al., 1985b). With regard to an action of progesterone on the time of onset of the LH surge, it has been shown that, in anoestrous ewes, induction of LH surges from 24 to $72 \mathrm{~h}$ after progesterone pretreatment ensures full-length cycles (McLeod \& Haresign, 1984; Legan et al., 1985b; Pearce et al., 1987). However, it remains to be determined whether the brief increments in progesterone which occur before the first full-length cycle at the beginning of the breeding season delay the LH surge.

Another mechanism whereby progesterone might ensure initiation of full-length luteal phases by an ensuing LH surge is to increase ovarian response to circulating gonadotrophins. This possibility receives support from the observation that administration of progesterone to anoestrous ewes before induction of an $\mathrm{LH}$ surge increased in-vitro oestradiol production and binding of ${ }^{125} \mathrm{I}$ labelled human chorionic gonadotrophin to granulosa cells from follicles which were removed just before and $2 \mathrm{~h}$ after onset of the LH surge (Hunter et al., 1986). Although the results presented herein indicate that preovulatory serum LH concentrations were not different before a transient progesterone rise from those observed before a full-length luteal phase, it remains to be determined whether the preovulatory rise in oestradiol which occurs before a transient rise in progesterone is less than that which precedes a full-length cycle.

Progesterone might also act by modulating tonic FSH concentrations during or immediately after the transient rise in progesterone, such that follicular maturation is optimal at the next LH surge, and hence a full-length luteal phase ensues. Finally, progesterone may exert an indirect luteotrophic effect on the newly-formed corpus luteum by inhibiting release of prostaglandin (PG) F- $2 \alpha$ from the uterus or by decreasing ovarian response to PGF-2 $\alpha$. Whatever the mechanism whereby progesterone ensures full-length luteal phases, its site of action in this regard also remains to be determined.

Although the observed rise in mean serum LH just before the first LH surge was not different from that which preceded the second surge, both of these 2-fold increments in tonic LH were lower than the 4-5-fold increase observed during the late follicular phase in the mid-breeding season (Karsch et al., 1979). Most of this difference can be accounted for by the difference in potency of the respective ovine LH standards used in the assays, our standard being 1.86 times more potent. In addition, some of the difference may reflect the seasonal modulation of the response to oestradiol negative feedback, such that during the transition period and early breeding season the negative feedback action of oestradiol, though diminished, is still more evident than in the mid-breeding season.

In 2 ewes, a transient rise in progesterone was observed 9 or 10 days before the first full-length luteal phase. This delay between the first short cycle and the second LH surge may reflect a shortlived rebound in the response to oestradiol negative feedback such that the next rise in tonic LH and subsequent LH surge was prevented for a time. This is supported by the observation that serum LH concentrations fluctuate markedly over a 17-day period as they increase in individual ovariectomized, oestradiol-treated ewes, at a time coincident with the transition from anoestrus to the breeding season in intact ewes (Legan et al., 1977).

The occurrence of an insufficient luteal phase at the transition to breeding season is rare. In most cases, whenever the first increase in progesterone concentrations lasts longer than 2 days, 
serum progesterone concentrations remain elevated above at least $2 \mathrm{ng} / \mathrm{ml}$ for about 10-12 days (Yuthasastrakosol et al., 1975; Walton et al., 1977; I'Anson \& Legan, 1988).

In conclusion, these results suggest that, although the seasonal decrease in oestradiol negative feedback is sufficient for initiation of the first LH surge of the breeding season, additional endocrine mechanisms may be necessary to induce the first full-length luteal phase. The current working hypothesis for the neuroendocrine control of onset of the breeding season may therefore be expanded to include the findings reported herein. Namely, the seasonal decrease in oestradiol negative feedback which occurs during the transition into breeding season allows an increase in tonic LH secretion which stimulates a rise in serum oestradiol causing an $\mathbf{L H}$ surge and subsequent ovulation (Legan \& Karsch, 1979). If there is a mature follicle present at the time of the LH surge, a full-length luteal phase will ensue; if not, which is generally the case, a transient rise in progesterone or short luteal phase will follow. The response to oestradiol negative feedback will either increase once again to a level high enough to prevent another increase in tonic $\mathrm{LH}$ for a period of time following this first luteal phase or it will remain low, allowing another rise in tonic LH secretion. If this second rise in tonic LH occurs soon after the first luteal phase and is sustained long enough to initiate an LH surge, it will always initiate a full-length cycle. Once the decrease in response to oestradiol negative feedback is sustained for more than a few days, full-length oestrous cycles will recur. Since follicular development during anoestrus is random in relation to the photoperiodinduced decrease in response to oestradiol negative feedback, the onset of full-length cycles at the beginning of the breeding season will be immediately preceded by a short luteal phase in the majority of ewes.

We thank Dr Gordon D. Niswender and Dr Leo E. Reichert, Jr, for graciously providing reagents for radioimmunoassay; Dr F. J. Karsch, Dr D. L. Foster, Dr R. L. Goodman and Dr K. D. Ryan for expert assistance in the design and execution of this study; $\mathrm{Mr} \mathrm{D}$. Doop for invaluable help in the conduct of the experiment and animal husbandry; and Ms Marilee Van Arsdall for performing RIAs. This work was supported by NIH-HD-14039 and NSF-PCM-8302959.

\section{References}

Berardinelli, J.G., Dailey, R.A., Butcher, R.L. \& Inskeep, E.K. (1980) Source of circulating progesterone in prepubertal ewes. Biol. Reprod. 22, 233-236.

BonDurant, R.H., Darien, B.J., Munro, C.J., Stabenfeldt, G.H. \& Wang, P. (1981) Photoperiod induction of fertile oestrus and changes in LH and progesterone concentrations in yearling dairy goats (Capra hircus). J. Reprod. Fert. 63, 1-9.

Doring, G.K. (1969) The incidence of anovular cycles in women. J. Reprod. Fert., Suppl. 6, 77-81.

Foster, D. (1977) Luteinizing hormone and progesterone secretion during sexual maturation of the rhesus monkey: short luteal phases during the initial menstrual cycles. Biol. Reprod. 17, 584-590.

Foster, D.L. \& Ryan, K.D. (1979) Mechanisms governing onset of ovarian cyclicity at puberty in the lamb. Annls Biol. anim. Biochim. Biophys. 19, 1369-1380.

Foster, D.L., Karsch, F.J., Olster, D.H., Ryan, K.D. \& Yellon, S.M. (1986) Determinants of puberty in a seasonal breeder. Recent Progr. Horm. Res. 42, 331-384.

Gibori, G., Antczak, E. \& Rothchild, I. (1977) The role of estrogen in the regulation of luteal progesterone secretion in the rat after day 12 of pregnancy. Endocrinology 100, 1483-1495.

Gonzalez-Padilla, E., Wiltbank, J.N. \& Niswender, G.D.
(1975) Puberty in beef heifers. I. The inter-relationship between pituitary, hypothalamic and ovarian hormones. J. Anim. Sci. 40, 1091-1104.

Goodman, R.L. \& Karsch, F.J. (1981) The hypothalamic pulse generator: a key determinant of reproductive cycles in sheep. In Biological Clocks in Seasonal Reproductive Cycles, pp. 223-236. Eds B. K. Follett \& D. E. Follett. Wright, Bristol.

Gray, R.H., Campbell, O.M., Zacur, H.A., Labbok, M.H. \& MacRae, S.L. (1987) Postpartum return of ovarian activity in nonbreastfeeding women monitored by urinary assays. J. clin. Endocr. Metab. 64, 645-650.

Hunter, M.G., Southee, J.A., McLeod, B.J. \& Haresign, W. (1986) Progesterone pretreatment has a direct effect on GnRH-induced preovulatory follicles to determine their ability to develop into normal corpora lutea in anoestrous ewes. J. Reprod. Fert. 76, 349-363.

I'Anson, H. \& Legan, S.J. (1988) Changes in LH pulse frequency and serum progesterone concentrations during the transition to breeding season in ewes. $J$. Reprod. Fert. 82, 341-351.

Karsch, F.J. (1980) Seasonal reproduction: a saga of reversible fertility. The Physiologist 23, 29-38.

Karsch, F.J., Foster, D.L., Legan, S.J., Ryan, K.D. \& 
Peter, G.K. (1979) Control of the preovulatory endocrine events in the ewe: interrelationship of estradiol, progesterone, and luteinizing hormone. Endocrinology 105, 421-426.

Karsch, F.J., Legan, S.J., Ryan, K.D. \& Foster, D.L. (1980a) Importance of estradiol and progesterone in regulating $\mathrm{LH}$ secretion and estrous behavior during the sheep estrous cycle. Biol. Reprod. 23, 404-4I3.

Karsch, F.J., Goodman, R.L. \& Legan, S.J. (1980b) Feedback basis of seasonal breeding: test of an hypothesis. J. Reprod. Fert. 58, 521-535.

Keisler, D.H., Inskeep, E.K. \& Dailey, R.A. (1983) First luteal tissue in ewe lambs: influence on subsequent ovarian activity and response to hysterectomy. $J$. Anim. Sci. 57, 150-156.

Legan, S.J. \& Karsch, F.J. (1979) Neuroendocrine regulation of the estrous cycle and seasonal breeding in the ewe. Biol. Reprod. 20, 74-85.

Legan, S.J., Karsch, F.J. \& Foster, D.L. (1977) The endocrine control of seasonal reproductive function in the ewe: a marked change in response to the negative feedback action of estradiol on luteinizing hormone secretion. Endocrinology 101, 818-824.

Legan, S.J., I'Anson, H., Fitzgerald, B.P. \& Fitzovich, D. (1985a) Does the seasonal increase in estradiol negative feedback prevent $\mathrm{LH}$ surges in anestrous ewes by suppressing hypothalamic GnRH pulse frequency? Biol. Reprod. 33, 117-131.

Legan, S.J., I'Anson, H., Fitzgerald, B.P. \& Akaydin, M.S., Jr (1985b) Importance of short luteal phases in the endocrine mechanism controlling initiation of estrous cycles in anestrous ewes. Endocrinology 117, $1530-1536$.

McLeod, B.J. \& Haresign, W. (1984) Evidence that progesterone may influence subsequent luteal function in the ewe by modulating preovulatory follicle development. J. Reprod. Fert. 71, 381-386.

McLeod, B.J., Haresign, W. \& Lamming, G.E. (1982a) The induction of ovulation and luteal function in seasonally anoestrous ewes treated with small-dose multiple injections of Gn-RH. J. Reprod. Fert. 65, 215-221.

McLeod, B.J., Haresign, W. \& Lamming, G.E. (1982b) Response of seasonally anoestrous ewes to smalldose multiple injections of $\mathrm{Gn}-\mathrm{RH}$ with and without progesterone pretreatment. J. Reprod. Fert. 65, 223-230.

McNatty, K.P., Ball, K., Gibb, M., Hudson, N. \& Thurley, D.C. (1982) Induction of cyclic ovarian activity in seasonally anoestrous ewes with exogenous GnRH. J. Reprod. Fert. 64, 93-96.
McNatty, K.P., Hudson, N.L., Henderson, K.M., Lun, S., Heath, D.A., Gibb, M., Ball, K., McDiarmid, J.M. \& Thurley, D.C. (1984) Changes in gonadotrophin secretion and ovarian antral follicular activity in seasonally breeding sheep throughout the year. $J$. Reprod. Fert. 70, 309-321.

Nass, T.E., Dierschke, D.J., Clark, J.R., Meller, P.A. \& Schillo, K.K. (1979) Luteal phase deficiencies in peripubertal rhesus monkeys: mechanistic considerations. In Ovarian Follicular and Corpus Luteum Function, pp. 519-525. Eds C. P. Channing, J. M. Marsh \& W. A. Sadler, Plenum Press, New York.

Niswender, G.D., Reichert, L.E., Jr, Midgley, A.R., Jr \& Nalbandov, A.V. (1969) Radioimmunoassay for bovine and ovine luteinizing hormone. Endocrinology 84, 1166-1173.

Oldham, C.M. \& Martin, G.B. (1978) Stimulation of seasonally anovular Merino ewes by rams. II. Premature regression of ram-induced corpora lutea. Anim. Reprod. Sci. 1, 291-295.

Pearce, D.T., Martin, G.B. \& Oldham, C.M. (1985) Corpora lutea with a short life-span induced by rams in seasonally anovulatory ewes are prevented by progesterone delaying the preovulatory surge of $\mathrm{LH}$. $J$. Reprod. Fert. 75, 79-84.

Pearce, D.T., Oldham, C.M., Haresign, W. \& Gray, S.J. (1987) Effects of duration and timing of progesterone priming on the incidence of corpora lutea with a normal life-span in Merino ewes induced to ovulate by the introduction of rams. Anim. Reprod. Sci. 13, 81-89.

Pope, G.S., Gupta, S.K. \& Munro, I.B. (1969) Progesterone levels in the systemic plasma of pregnant, cycling, and ovariectomized cows. J. Reprod. Fert. 20, 369-381.

Robinson, J.E. \& Karsch, F.J. (1984) Refractoriness to inductive daylengths terminates the breeding season of the Suffolk ewe. Biol. Reprod. 31, 656-663.

Walton, J.S., McNeilly, J.R., McNeilly, A.S. \& Cunningham, F.J. (1977) Changes in concentrations of follicle-stimulating hormone, luteinizing hormone, prolactin and progesterone in the plasma of ewes during the transition from anoestrus to breeding activity. J. Endocr. 75, 127-136.

Yuthasastrakosol, P., Palmer, W.M. \& Howland, B.E. (1975) Luteinizing hormone, oestrogen and progesterone levels in peripheral serum of anoestrous and cyclic ewes as determined by radioimmunoassay. J. Reprod. Fert. 43, 57-65.

Received 11 August 1987 